\title{
Antecedents of Anti-Branding: An Empirical Research for Managerial Perspective
}

\author{
Ramazan Kaynak $^{1}$ \& Sevgi Ekşi ${ }^{1}$ \\ ${ }^{1}$ Gebze Institute of Technology, Faculty of Business Administration, Turkey \\ Correspondence: Ramazan Kaynak, Gebze Institute of Technology, Faculty of Business Administration, 41400 \\ Gebze-Kocaeli, Turkey. Tel: 90-262-6051427. E-mail: kaynak@gyte.edu.tr
}

Received: July 3, 2013

Accepted: July 22, $2013 \quad$ Online Published: September 23, 2013

doi:10.5539/ibr.v6n10p78

URL: http://dx.doi.org/10.5539/ibr.v6n10p78

\begin{abstract}
This study reveals prevalent antecedents of the behaviors of anti-branding communities on the internet. In the theoretical framework, the impacts of ethnocentrism, religiosity, environmental and health consciousness upon anti-branding are investigated. The empirical results of the study put forth important findings in terms of understanding the main motives behind anti-branding. This study also offers noteworthy implications for researchers and marketing managers by revealing the relationship between ethnocentrism, environmental and health consciousness and anti-branding while taking gender and education as control variables.
\end{abstract}

Keywords: anti branding, ethnocentrism, religiosity, environmental, health consciousness

\section{Introduction}

While traditional consumer studies primarily deal with positive consumption of products, interest in negative attitudes of consumers towards products and brands such as resistance, avoidance anti-consumption are growing (Lee et al., 2009) due to market conditions. Globalization, free market implications and competition highlight the importance of sustainable competitive power, which requires consumer satisfaction and loyalty. Anti-branding practices occur in a great deal of forms; consumer rebellion, consumer resistance, boycotting, counter-cultural movements and non-consumption (Cherrier, 2009). The common characteristic of all these forms is to resist the strength and impacts of consumer culture imposed by certain brands (Penaloza \& Price, 2003). Mass production has triggered overconsumption continuously and this culture has destroyed both environment and human health. These negative outcomes awaken people awareness towards unconscious consumption and reshape their purchasing decision. Turkish people living in a digitally emerging context utilize the advantages of the internet to increase participation and cooperation among the people having similar tendencies towards consumerism and global brands in order to avoid these brands as a collective identity. Thanks to World Wide Web, restrictions of space and time have been eliminated, which enhance their impacts upon the targeted brands (Shepard \& Hayduk, 2002).

In order to define anti-branding and main motivators behind them efficiently, the outstanding motives supporting consumption might be focused. Røpke (1999) explains consumption in three main perspectives in his study. Through a broader perspective, he states the importance of economic motivators like reduced costs through mass production and competition. From a socio psychological perspective, the writer emphasizes human beings' need for goods to make sense of the world hierarchically. Lastly, the narrowest point of view depending on personal needs like desires, emotions and social relations. While competition may encourage some consumers to consume certain brands by including all of these perspectives, it also leads some consumers to avoid certain brands since they restrict their freedom and power. Consumer technological, economic, social and legal empowerment (Krishnamurthy \& Küçük, 2009) enable them to reject and protest certain brands more quickly and collectively by focusing on the negative aspects of certain brands in a various platform. In terms of desires and emotions, modern people begin to realize the absence of spirituality and they desire for a simpler life, where they could enhance their humane side. They share the advantages of restricted consumption on online discussion boards. Therefore, more consumers become apt to consume less and resist certain brands imposing consumer culture in order to increase their personal satisfaction. Besides anti-consumers caring for their well-being, some other consumers form their purchasing behavior by taking other people and environment into consideration and give importance to negative global impacts of consumption culture upon environment, as well. In terms of social 
relations and social status, people display resistance against certain products and brands by considering reference group incongruity. For instance, an online anti-Starbucks community in Turkey argues this brand utilizes our water resources irresponsibly besides it destroys our ethnic values, traditions and imposes assimilation. Such communities may show their resistance overtly and in a more collectivist approach such as rebellions and boycotts. The research question which is to be analyzed throughout this study is about understanding anti branding more efficiently by revealing the main motives that trigger them to react against consumption and highlighting the importance of these motives in terms of constructing corporate policies and marketing strategies so that companies can also satisfy these resisting consumers' expectations from companies and products. In the following part, the relationship between anti-branding and the determined antecedents, ethnocentrism, religiosity, environmental and health consciousness, will be discussed through the light of related literature.

\section{Antecedents of Anti-Branding}

Since consumers express themselves and their identities through the brands they use, they might tend to avoid certain products and brands because of the incongruity between the brand and their self concepts (Aaaker, 1999; Krishnamurty \& Küçük, 2009). Lee et al. (2009) classify these specific concerns under three primary categories which are experiential avoidance resulted from unmet expectations, identity avoidance led by symbolic incongruence and moral avoidance by ideological incompatibility. When a certain brand or product does not satisfy consumer's expectations, it diverts consumer preference to other alternatives after this negative experience. Secondly, certain products or brands display the image of undesired self in consumer's perception; consumer might resist purchasing these products. Lastly, against the products of certain companies ignoring corporate responsibility and certain countries perceived as supporting power inequality might be the reason of resisting against certain brands. Iyer and Muncy (2008) state that consumers' anti-loyalty towards certain brands or product conveys individual's commitment to avoidance of buying a brand because of negative experience related to it and perceived inferiority associated with product, personal and social factors play crucial roles in forming consumer's purchasing decision and determine consumer's attitude towards certain products and brands. Online platforms increase the speed and impact of Word of Mouth actions which are crucial for consumers to obtain market information and develop anti-branding attitudes (Assael, 1995). Carrying out WOM actions against certain brands has led people to resist certain brands more collectively by informing and encouraging other members of online communities.

\subsection{Ethnocentrism}

The concept of ethnocentrism could be defined as the view of the world in which one's own group is center of everything and all others are evaluated with reference to this group (Sumner, 1906). The other groups and their belongings are rated according to this group's value system. Since people classify their surroundings according to their ethnical culture and form their attitudes towards others this sociological concept also affect their preferences. Consumers and their purchasing preferences driven by the concept of ethnocentrism have been focused by various marketing studies (Shimp \& Sharma, 1987; Klein \& Ettenson, 1999; Balabanis \& Diamantopoulos, 2004). Consumer ethnocentrism may be described as the priority of locally produced products and a bias against foreign made products (Sharma, Shimp, \& Shin, 1995).

Ethnocentric people are against foreign brands as they believe that purchasing these brands will hurt domestic economy, cause loss of jobs and increase the power of capitalist companies and dependency of poorer economies to them. The inequality and forced dependency that global companies cause may increase the negative attitudes of consumers against these companies' products since they support the practice of buying from socially responsible producer (Huneke, 2005).

Global brands having lower production costs and higher competitive power may be perceived as harmful competitors by ethnocentric consumers since these companies may harm their own country's economy. Ethnocentric consumers have believed purchasing foreign brands/products is inappropriate indeed immoral (Shimp \& Sharma, 1987). Besides, their oppression upon economy, they may also ignore environmental disasters they cause while struggling for a cheaper production and utilizing natural resources as if they were infinite. These attitudes of global companies could awaken the awareness of consumers and these consumers might avoid buying the products of the global brands. Therefore, it could be asserted that ethnocentric consumers are more sensitive towards foreign brands' operations and their products' harmful effects on consumers and this sensitivity encourages their resistance against foreign brands. Consumer's attitudes have crucial impacts upon their purchasing behavior and ethnocentric people have prejudice against imported products/brands as they are loyal to their own country (Shankarmahesh, 2006). There are mainly three points which trigger ethnocentric consumers to avoid foreign brands. First of all, their love for their country and their concerns for their country's 
economic conditions and workforce hinder them from buying imported brands. They believe that purchasing imported brands will harm the country's own economy; factories could not survive and lose their sustainable competitive powers against global rivalries. Furthermore, buying imported products is inappropriate morally for ethnocentric consumers. Patriotic feelings of consumers even may lead them to prefer lower-qualified or less economical local brand. In conclusion, ethnocentric consumers' avoidance from foreign brands/products could stem from personal values and tendencies toward foreign brands/products (Sharma et al., 1995). Thence, an ethnocentric consumer would be more likely to favor anti-branding.

Braunsberger and Buckler (2011) emphasize the feeling of guilt and its crucial impact upon consumers' purchasing behavior. For instance, anti McDonalds and KFC Online communities encourage consumers not to buy these brands since they force consumers to assimilation by ignoring their ethnical values besides their irresponsible attitudes towards environment by harming Amazon forests to over consume soybeans. These brands also harm local companies and cause unemployment therefore online communities resist the Avoiding them collectively. Negative emotion resulted from violating one's own value system could motivate consumers to participate in boycotts against certain brands. Lambert and Harrolt (2010) also state in their study that buying imports is unpatriotic, causes unemployment and has destructive upon countries' economy for ethnocentric consumer. In this context, consumer's sovereignty could be utilized against foreign brands through collective resistance against these products (Kozinets \& Handelmann, 2004). Thus, it could be asserted that ethnocentric consumers are more likely to be motivated by their ethnocentricity while acting against certain brands in various platforms.

H1. Ethnocentrism has a positive impact on anti-branding.

\subsection{Religiosity}

Stolz (2009) defines religiosity as individual preferences, feelings, beliefs, and actions representing an existing (or self-made) religion and in this context 'Religion' may be defined as the whole of cultural symbol-systems managing the problems of meaning and contingency through a transcendent reality influencing individuals everyday life, values, attitudes, behaviors and preferences. Considering its relevance to business world, exploratory role of religiosity in explaining consumer behavior is highly precious in today's competitive global markets (Moschis \& Ong, 2011). Commitment to religious values effects consumer purchasing behavior (Francis \& Kaldor, 2002; Mokhlis, 2009; Choi, 2009). Consumer faithfulness might hinder consumers from buying brands that are not compatible with their religious beliefs. Online communities boycotting Israel's brands assert that consumers' buying these brands backs up the war resulting in the death of many Palestine victims and these brands are threats for their religious values, as well. Active discussion boards and informative news about their negative outcomes in terms of religiosity strengthen the impact and scope of such collective identities.

While examining the relevance of religiosity to anti-branding, religious consumer's common aim may also be defined as enhancing well-being in terms of self esteem, life satisfaction and health (Moschis \& Ong, 2011). Simplifying the material life and increasing spirituality are emphasized both by some consumers favoring anti-branding and religiosity. Religiosity support devotion to spiritual life and detachment from worldly materialistic concerns (Vermeir \& Verbeke, 2008). Schwartz and Huismans (1995) compare the concepts of religiosity and universalism in their study and propose that unity with nature; environmental concerns and broadmindedness are more associated with universalism rather than religiosity.

Definition of anti-loyal consumers highlights their avoidance from certain products or brands instead of a general decrease in their consumption (Iyer \& Muncy, 2008). As religiosity might shape consumer's preferences; it could be overtly inferred that consumer could refrain from certain brands which are not in accordance with their religious values (Bonne \& Verbeke, 2006) and share their avoidance through anti-branding websites. Rey (2004) states in his study that the religious markets, like any other markets, are arena of competition and therefore companies should consider importance of offering the products caring consumers' religious beliefs while marketing their goods and increasing religious capital otherwise, consumers become resistant against certain brands and switch to other alternative brands which are more proper according to their religious beliefs. Thus, it could be asserted that more religious consumers tend to behave in accordance with the attitudes of consumers favoring anti-branding

Some consumers voice their resistance towards certain brands through boycotting. Religion could provide salvation for people through ontological assumptions (Barrett, 2000).These assumptions could define values, beliefs, norm systems and behaviors of individuals. Such a holistic transcendent system may trigger people to resist certain products or brands in order to punish them as a result of their perceived disrespectful practices and policies against their value system or other members of their religion. Farah and Newmann (2010) state in their 
study focusing on the Middle East, outstanding effect of religion upon consumers boycotts violating American brands due to US policy in that area. Market activists utilize brand boycotts as a means of expressing their anger toward certain company or brands (Hoffman \& Müller, 2009) and these platforms enhances their impact on these brands and their market share.

H2. Religiosity has a positive impact on anti-branding.

\subsection{Environmental Consciousness}

Recently, global awareness towards environment and ecological balance has risen respectfully due to certain global environmental objectives such as tackling climate change, preserving the world's natural resources, or combating poverty (Campbell, 1990). Schlegelmilch, Bohlen and Diamantopoulos (1996) describe environmental consciousness as a motive raising individuals' awareness of the negative environmental outcomes associated with humankind careless behaviors as well as companies, products or brands and reshaping their attitudes and behaviors in order to decrease hazards of these agents' operations upon nature. Environmental consciousness may encourage anti branding. Cherrier (2009) emphasizes awareness of environmental impacts of extravagance and wasteful consumption make consumers to react against consumer culture and the brands imposing this culture. Thus, an environmentally conscious consumer is more likely to support general anti-consumption of these brands to increase their own life satisfaction by caring for nature. Through education system, globalization and various media means people awareness toward environmental problems has increased significantly and their purchasing decisions are also formed by considering ecological and social sustainability (Vermeir \& Verbeke, 2008). Therefore, environmentally conscious consumers are more likely to resist brands imposing consumer culture due to their tremendous hazards upon ecological sustainability.

In addition, consumers may avoid certain brands morally because of symbolic incongruence and ideological incompatibility (Lee et al., 2009). These consumers easily switch from brands which cannot satisfy environmental expectations to greener alternatives since they associate certain products or brands ignoring their harmful effects upon environment with undesired self and they avoid these products. Furthermore, anti-loyal consumers may resist oppressive capitalist brands since they do care only for their profits and overlook environmental problems that they cause. Lastly, market activists determine their resistance against certain products or brands by taking their social and environmental impacts into consideration. Most boycotts supported by consumers have social and ecological concerns ranging from environmental concerns, global labor standards, and animal welfare to waste management (Diermeier \& Van Mieghem, 2008). Boycotts are perceived as powerful means to force brands to become more environmentally conscious institutions. That's to say; environmentally conscious consumers are more likely to participate in market activists' boycotts towards certain brands. Environmental consciousness has increased thanks to anti-branding websites, online informative blogs and discussion boards. For example, an online community revealed the deficiencies of L'Oreal in terms of animals welfare although this brand highlights its respectable corporate responsibility in terms of waste management and such communities effect numerous people more quickly and directing them to become a member of these online communities in order to voice their environmental consciousness collectively.

H3. Environmental consciousness has a positive impact on anti-branding.

\subsection{Health Consciousness}

Michaelidou and Hassan (2008) define health-consciousness as being aware and concerned about individual's own state of well-being and motivated to improve and/or maintain his/her health and quality of life, as well as preventing ill health by engaging in healthy behaviors (Michaelidou \& Hassan, 2008). Health conscious consumers are trying to pursue a sustainable lifestyle through considering health and environmental impacts of their daily routines. Health consciousness can also be described as the degree to which health concerns are included into a person's daily life (Jayanti \& Burns, 1998). Health conscious consumers have a consistent preference for healthier alternatives of products.

Health consciousness could trigger consumers' resistance both for general and specific reasons. Cherrier (2009) states in her study that consumers desperately consume products that they do not need in an attempt to feel better, to feel happy and this dependency to material possessions cause emotional distortions, meaningless lives or unhealthy behaviors.

Avoiding the oppression of consumer culture may release people to get rid of such negative outcomes. Grisby (2004) states that there should be a limitation of properties since possession of many things puts forth so many possible choices and decisions to made, which becomes a nervous strain and harms psychological health. Consumers avoiding brands having unhealthy practices and products and they devote their lives to a simpler life 
to become healthier. Therefore, health conscious consumers tend to seize on a simple life by means of avoiding brands favoring consumption culture hegemony.

Consumption of brands which harm society's health may also be perceived as an immoral behavior since this may lead to moral in congruency (Lee et al., 2009). Consumers giving importance to societies' health, equality and sustainability could not appreciate the consumption of brands having unhealthy products. Instead, they could switch to healthier alternatives and encourage other people having similar point of views by using the strength of WOM to punish these brands through online platforms. Thence, health conscious consumers have higher possibility of displaying attitudes supporting anti-branding.

Consumers can also harm many brands because of their materialistic practices ignoring community's health. For instance, companies like McDonalds, Starbucks or Wal-Mart impose consumers to become a dependent stereotype in the meaningless cycle of overconsumption (Hollenbeck \& Zinkhan, 2006). Overconsumption of unhealthy products may result in illnesses such as obesity (Currie, Della Vigna, Moretti, \& Pathania, 2009), heart disease or diabetes. Health conscious consumers participate more actively in sensitive communities to reveal and share unhealthy practices of these brands. To sum up, health conscious consumers are more likely to resist unhealthy products or brands through boycotts or by means of media.

H4. Health consciousness has a positive impact on anti-branding.

\section{Control Variables}

\subsection{Gender}

Many studies have highlighted the gender differences for ethnocentric consumers' tendencies (Balabanis et al., 2004; Sharma, Shimp, \& Shin, 1995; Shankarmahesh, 2006; Ramsaran-Fowdar, 2010; Rahman et al., 2011). Most of the related studies examining the gender differences in terms of ethnocentrism found out that male consumers tend to be less ethnocentric when compared to men (Balabanis et al., 2004; Klein \& Ettenson, 1999; Sharma et al., 1995; Shimp \& Sharma, 1987). There are some studies also investigating whether differences in gender might occur in terms of religious commitment (Worthington, Worthington, Wade, Hight, Ripley, McCullough, Berry, Schmitt, Berry, Bursley, \& O'Connor, 2003). Some studies assert that there is a significant difference in gender in terms of religion and most of them found out that women could have more religious tendencies while shaping their buying behavior (Miller \& Hoffman, 1995; Loewenthal et al., 2002). There have been also various studies focusing on differences in gender while examining the environmental concerns (Zelezny et al., 2000; Mostafa, 2007). While some studies assert female consumers are more environmentally conscious (Banerjee \& McKeage, 1994; Mostafa, 2007), some other studies put forth that males are more tend to shape their buying decisions by prioritizing environmental concerns (Reizenstein et al., 1974). Therefore, it is proposed that gender has a significant impact on environmental consciousness and women are more tend to be environmentally conscious. Lastly, studies analyzing differences in gender about health concerns have found out that women tend to be more health conscious than men (Fagerli \& Wandel, 1999).

\subsection{Education}

Many studies found that better educated consumers tend to be less ethnocentric (Balabanis et al., 2004; Sharma et al., 1995; Shankarmahesh, 2006). Watson and Wright (2000) also stated in their work that ethnocentric consumers were more likely to be less educated. When the relationship between educational attainment and religiosity, the literature mostly support the idea of well-educated people have low religiosity (Stroope, 2011). Less educated people were more likely to have lower consciousness about environment and they tend to consider environmental protection less important (Wang \& Reisner, 2011). The related literature about educational attainment and health consciousness assert that higher educated people are more likely to acquire health information behavior and attain a healthier life style (Divine \& Lepisto, 2005).

\section{Research Methodology}

\subsection{Data Collection and Sample}

The purpose of this study is to understand the main antecedents triggering anti-brand communities; this study has focused on respondents participating in online anti-brand communities and self identifying themselves as anti-consumers. First of all, Turkish online anti-consumer and anti-brand communities were investigated. Opposition of web communities to popular and international brand names was analyzed. Then, active online communities were sent an online survey including the proposed antecedents and anti-branding. In accordance with the related literature, these online communities' state arguments related to the proposed relationships between ethnocentrism, religiosity, environmental and health consciousness and anti-branding. Some of their quotes were indicated below to understand their perspectives holistically. 


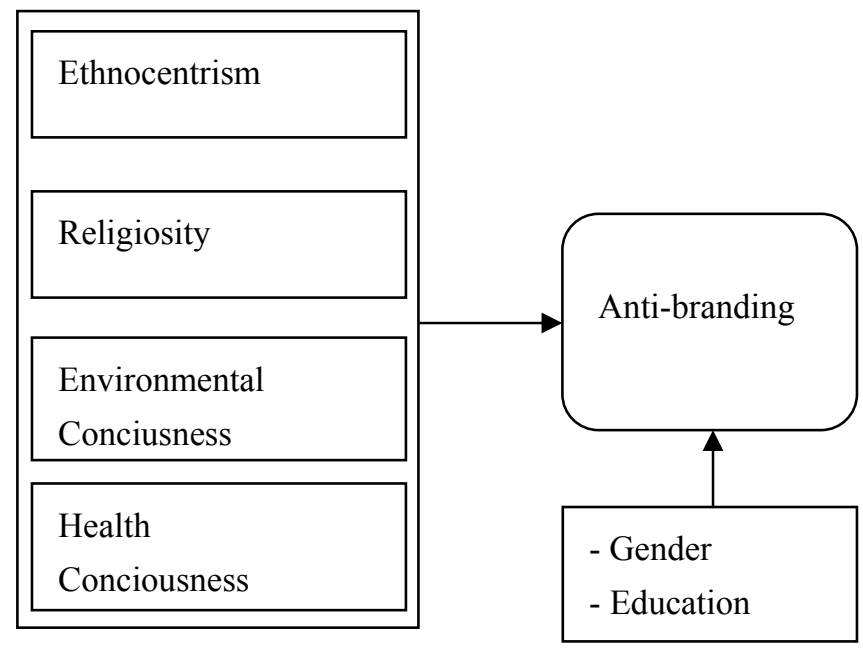

Figure 1. Research model

These groups are formed to support several behavioral manifestations such as publicizing marketplace inequalities and unethical practices, informing other people about the positive outcomes of restrictive life styles (e.g., voluntary simplifiers) in a more convenient, quick way thanks to virtual formation and resisting as a collective identity (Hollenbeck \& Zinkhan, 2002).

In this study, online communities typically focusing on common desires to limit consumption. Members resisted against consumerism collectively. They react actively against certain brand because of their unhealthy and irresponsible practices towards their surroundings and others' main values such as religion and ethnic identities. Following are some excerpts from anti-brand websites, related communities' blogs and discussion boards conveying the relevance of the proposed antecedents to anti-branding.

Coca-cola harms our religious beliefs, coca cola imposes overconsumption and when its name is read from right to left, it is similar to "La Mohammed la Mecca" its meaning is "No Muhammed No Mekke", it aims to harm our religion (Anti Coca cola community).

Avoid McDonalds since it estranges us from our own ethnic meals and it also has tremendous negative effects upon our health (Anti-McDonalds online community).

Adidas cannot discard poisonous chemicals from its supply chain; it also carries out experiments upon animals. L'Oreal is also ignoring animals' lives and their importance in terms of ecology (Greenpeace, Mediterranean).

Research data were collected by means of an electronic survey in order to address to a great deal of respondents. Several posts were sent to anti-brand websites, well known anti-consumer forums and blogs. A specific link was sent to potential interviewees where they could reach the whole questionnaire. Totally, 520 questionnaires were returned; however, seventeen respondents were found a low level of confidence in their responses and were dropped. Finally, 503 questionnaires were included in the analysis process. Fifty two percent of the respondents $(\mathrm{n}=260)$ were male while forty eight percent of the respondents were female $(\mathrm{n}=243)$. Additionally, $69 \%(\mathrm{n}=$ 348 ) of the respondents indicated that they are at least bachelor's degree holders.

\subsection{Measures}

The ethnocentrism scale used in this study which is consisted of four items was taken from the reduced CETSCALE (Consumer Ethnocentrism Scale) developed by Steenkamp, Batra and Alden (2003), which was validated in the study of Winit, Gregory and Mascio (2008). Religious commitment scale included in the questionnaire was developed in the study of Worthington et al. (2003). While assessing the religiosity this study tried to emphasize religious commitment as religion is highly personal in nature and its impacts on consumer behavior depend on mainly individuals' level of religious commitment (Mokhlis, 2009). In order to evaluate environmental consciousness of the consumers, we used a scale including five items adapted from New Environmental Paradigm-NEP (Roberts \& Bacon, 1997). For the measurement of health consciousness, the scale reexamined in Hong (2009) proposed by Dutta-Bergman $(2004 ; 2006 ; 2007)$ was included in the survey. Anti-branding scale was adapted from the study of Lee et al. (2009). The original scale items were translated into Turkish and back-translated and then transcribed by a bilingual person fluent in Turkish and English. All constructs were measured with already existing reliable scales. All items were measured on a five point 
Likert-type scale where $1=$ strongly disagree and $5=$ strongly agree.

\subsection{Assessing Validity and Reliability}

Before the detailed analysis, several underlying assumptions were checked. The fundamental statistical assumptions for factor analysis were: sampling adequacy, and normality (Hair et al., 1998). Kaiser-Meyer-Olkin's measure of sampling adequacy was 0.884 , and Bartlett's Test of Sphericity index was significant $(\mathrm{p}<0.01)$. Convergent validity was assessed by examining the factor loading for statistical significance (Sujan, Weitz, \& Kumar, 1994). As indicated in Table 1, all factor loadings were statistically significant $(\mathrm{p}<0.05)$ within an acceptable range (from 0.72 to 0.96 ); thus providing strong evidence of convergent validity.

\subsection{Data Analysis and Results}

We calculated means and standard deviations for each variable and created a correlation matrix of all variables used in hypothesis testing. Means, standard deviations, reliabilities, and correlations among all scales used in the analyses are shown in Table 2. The means and standard deviations are within the expected ranges.

Table 1. Construct measurement items, cronbach's alpha and factor loadings

\begin{tabular}{|c|c|c|}
\hline Constructs & Measurement items & $\begin{array}{l}\text { Factor } \\
\text { Loadings }\end{array}$ \\
\hline Etnocentrism & $\begin{array}{l}\text { 1.Turkish people should not buy foreign products because this hurts Turkish business and causes } \\
\text { unemployment }\end{array}$ & .744 \\
\hline \multirow[t]{3}{*}{$(\alpha=.796)$} & 2.It is not right to purchase foreign-made products & .782 \\
\hline & 3.A real Turkish people should always buy Turkish made products & .748 \\
\hline & 4.Turkish people support Turkish products even if they might be more expensive & .677 \\
\hline Religiosity & 1.My religious beliefs lie behind my whole approach to life & .754 \\
\hline \multirow[t]{9}{*}{$(\alpha=.927)$} & 2.I spend time trying to grow in understanding of my faith & .781 \\
\hline & 3.It is important to me to spend periods of time in private religious thought and reflection & .815 \\
\hline & 4.Religious beliefs influence all my dealings in life & .799 \\
\hline & 5.Religion is especially important to me because it answers many questions about the meaning of life & .773 \\
\hline & 6.I often read books and magazines about my faith & .822 \\
\hline & 7.I enjoy working in the activities of my religious organization & .824 \\
\hline & 8.I enjoy spending time with others of my religious affiliation & .810 \\
\hline & 9.My religious beliefs lie behind my whole approach to life & .614 \\
\hline & 10.I spend time trying to grow in understanding of my faith & .676 \\
\hline Environmental & 1.The balance of nature is very delicate and easily upset & .526 \\
\hline Consciousness & 2.When humans interfere with nature, it often produces disastrous consequences & .675 \\
\hline \multirow[t]{3}{*}{$(\alpha=.711)$} & 3.Humans must live in harmony with nature in order to survive & .750 \\
\hline & 4.Mankind is severely abusing the environment & .674 \\
\hline & $\begin{array}{l}\text { 5.To maintain a healthy economy, we will have to develop a steady state economy where industrial growth is } \\
\text { controlled }\end{array}$ & .489 \\
\hline Health & 1.Living life in the best possible health is very important to me & .571 \\
\hline Consciousness & 2.Eating right, exercising, and taking preventive measures will keep me healthy for life & .729 \\
\hline \multirow[t]{3}{*}{$(\alpha=.792)$} & 3.My health depends on how well I take care of my self & .732 \\
\hline & 4.I actively try to prevent disease and illness & .723 \\
\hline & 5.I do everything I can stay healthy & .710 \\
\hline Anti-branding & 1.I don't buy a brand which has a poor performance & .659 \\
\hline$(\alpha=.790)$ & 2.I don't buy a brand which is incompatible with my expectations. & .679 \\
\hline
\end{tabular}


3.The store environment can lead me not to buy a brand.

4.Negative reference groups may lead me not to buy a brand.

5.I don't buy brands lacking of authenticity.

6.I don't buy brands favoring deindividuation.

7.I don't buy brands ignoring their corporate responsibilities.

Table 2. Descriptives and correlations of the measures

\begin{tabular}{|c|c|c|c|c|c|c|c|c|}
\hline & Mean & S.D. & $\alpha$ & 1 & 2 & 3 & 4 & 5 \\
\hline 1.Ethno & 3.62 & 0.93 & 0.796 & 1.000 & & & & \\
\hline 2.Relig & 3.15 & 0.98 & 0.927 & $.330 * *$ & 1.000 & & & \\
\hline 3.Envir & 3.89 & 0.61 & 0.711 & $.167 * *$ & 0.019 & 1.000 & & \\
\hline 4.Health & 4.12 & 0.71 & 0.792 & $.282 * *$ & $.166^{* *}$ & $.324 * *$ & 1.000 & \\
\hline 5.Anti-brand & 3.73 & 0.67 & 0.790 & $.156^{* *}$ & $.103 *$ & $.298 * *$ & $.340 * *$ & 1.000 \\
\hline
\end{tabular}

** Correlation is significant at the 0.01 level (2-tailed); * Correlation is significant at the 0.05 level (2-tailed);

$\mathrm{SD}=$ Standard Deviation $\alpha=$ Cronbach’s Alpha, Ethno= Ethnocentrism, Relig = Religiosity,

Envir $=$ Environmental $\quad$ Consciousness, Health= Health Consciousness, Anti-brand $=$ Anti-Branding

Table 3. The results of regression analysis

\begin{tabular}{|c|c|c|c|c|c|c|c|c|c|c|}
\hline \multirow[b]{2}{*}{$\begin{array}{l}\text { Independent } \\
\text { Variables }\end{array}$} & \multicolumn{2}{|c|}{$\begin{array}{l}\text { Model 1: } \\
\text { General }\end{array}$} & \multicolumn{2}{|c|}{$\begin{array}{l}\text { Model 2: } \\
\text { For females }\end{array}$} & \multicolumn{2}{|c|}{$\begin{array}{l}\text { Model 3: } \\
\text { For males }\end{array}$} & \multicolumn{2}{|c|}{$\begin{array}{l}\text { Model 4:At least } \\
\text { Bachelor's degree }\end{array}$} & \multicolumn{2}{|c|}{$\begin{array}{l}\text { Model 5: Below } \\
\text { Bachelor's degree }\end{array}$} \\
\hline & Beta & $\mathrm{t}$ & Beta & $\mathrm{t}$ & Beta & $\mathrm{t}$ & Beta & $\mathrm{t}$ & Beta & $\mathrm{t}$ \\
\hline Ethnocentrism & 0.100 & $2.330^{*}$ & 0.158 & $2.516^{*}$ & 0.080 & 1343 & 1480 & 2459 & 0.277 & $2.928^{*}$ \\
\hline Religiosity & 0.035 & 0.836 & -0.058 & -0.947 & 0.099 & 1697 & 0.721 & 0.782 & 0.076 & 0.821 \\
\hline $\begin{array}{l}\text { Environmental } \\
\text { consciousness }\end{array}$ & 0.292 & $7.070 * * *$ & 0.291 & $4.910 * * *$ & 0.265 & $4.535 * * *$ & 6590 & $4.407 * * *$ & 0.172 & 1827 \\
\hline Health & & & & & & & & & & \\
\hline Consciousness & 0.288 & $7.128 * * *$ & 0.299 & $5.198 * * *$ & 0.299 & $5.181 * * *$ & 6180 & $2.652 * * *$ & 0.284 & $3.129 *$ \\
\hline $\mathrm{F}$ & & $19.209 * * *$ & & $19.209 * * *$ & & $18.092 * * *$ & & $28.491 * * *$ & & $7.785^{* * *}$ \\
\hline Adjusted $\mathrm{R}^{2}$ & & 0.231 & & 0.231 & & 0.209 & & 0.215 & & 0.215 \\
\hline VIF & & $<1.181$ & & $<1.247$ & & $<1.167$ & & $<1.132$ & & $<1.202$ \\
\hline
\end{tabular}

Dependent variable: Anti- branding; $* \mathrm{p}<0.05 ; * * \mathrm{p}<0.01 ; * * * \mathrm{p}<0.001$

Research hypotheses were tested with a series of regression analyses. To investigate multicollinearity concerns, the independent variables creating interaction terms are focused. In all regression analyses, the variance inflation factors (VIF) are examined to assess multicollinearity among the predictors. All Variance Inflation Factor (VIF) scores are below 10, which indicate that multicollinearity does not represent a serious problem (Eye \& Schuster, 1998, p. 137).Furthermore; "tolerance" values for each predictor are analyzed in the research models as a check for multicollinearity. The "tolerance" could be defined as an indication of the percent of variance in the predictor that cannot be accounted for by the other predictors. Values that are less than .10 may merit further investigation however; none of the tolerance values are below .10.

Furthermore, Durbin Watson values are also analyzed to understand whether there is an autocorrelation problem in the model or not. The Durbin-Watson statistic provides the standard test for autocorrelation. Autocorrelation occurs when the error between the fitted and actual value is not independent from one observation to the next. A 
Durbin-Watson statistic between 1.5 and 2.5 indicates that there is not serious autocorrelation. The models proposed in this study have no significant autocorrelation since their Durbin Watson statistics are ranging between 1.828 and 2.31 .

The research model examines the effects of ethnocentrism; religiosity, environmental and health consciousness on anti-branding (see Model 1). Gender and age variables are taken as control variables. In the first model, the effects of ethnocentrism $(p<0.05)$, environmental and health consciousness $(p<0.01)$ on anti-branding were revealed to be statistically significant. In the second and third model, these antecedents' impacts upon anti-branding are examined in terms of gender, it is observed that besides environmental and health consciousness, ethnocentrism has a significant effect $(\mathrm{p}<0.05)$ on resisting against brands for female respondents while this antecedent has not a significant impact on male respondents. The fourth and fifth models figure out the effect of educational attainment of respondents while evaluating the impacts of ethnocentrism, religiosity, environmental and health consciousness on anti-branding. The forth model represents for respondents having at least bachelor's degree. In this model, ethnocentrism has not a significant effect on anti-branding while environmental and health consciousness have significant effects on anti-branding $(\mathrm{p}<0.01)$. The last model was developed to see the effects of the antecedents on anti-branding for the respondents having lower education level -below bachelor's degree-in which ethnocentrism and health consciousness have positive effects on anti-branding.

\section{Discussion and Conclusion}

\subsection{Discussion}

The conducted research and its results supported the proposition that anti-branding could be understood more comprehensively and foreseen more effectively by revealing consumers' tendencies about ethnocentrism, environmental and health consciousness. Both the correlations and regression analysis supported our hypothesis except for the hypothesis related to religiosity. These findings are vital since consumers supporting anti-branding have been growing in numbers (Holt, 2002; Krishnamurty \& Küçük, 2009).Revealing the main motivators behind anti-branding helps companies to develop strategies satisfying these consumers' needs and expectations related to these main factors and minimize the negative effects of online anti-branding websites.

This study empirically tested the effects of ethnocentrism, religiosity, environmental and health consciousness upon anti branding. Data were collected in Turkey where religiosity and ethnocentrism could have perceived as vital factors in shaping consumers' purchasing decisions (Shimp \& Sharma, 1987; Kaynak \& Kara, 2002; Nguyen, Nguyen, \& Nigel, 2008). The results of the analysis put forth some outstanding inferences both for academicians and companies. First of all, this study has revealed that health consciousness could be categorized as the main motivator of consumers who favor anti branding. While environmental consciousness has a significant effect on consumers having at least bachelor's degree, it has not a significant impact on consumers having education below bachelor's degree.

Secondly, in accordance with the findings of many studies related to ethnocentrism in terms of understanding consumer behavior (Sharma et al.,1995; Klein \& Ettenson, 1999; Mokhlis, 2009) the results of this study show that this antecedent has a positive significant impact upon anti-branding especially for female and low-educated consumers. This antecedent was proposed to have significant effects for consumers regardless of gender and educational attainment differences. When compared to their global high qualified alternatives, even poorer quality of local brands might be chosen by these ethnocentric consumers. Secondly, since Turkey has a developing economy, its production costs might not be sufficient for offering competitive price to consumers. Moreover, religiosity is also another emphasized antecedent while defining Islamic consumers purchasing behaviors in the related literature (Esso \& Dibb, 2004; Vitell, Singh, \& Paolillo, 2007; Farah \& Newmann, 2010; Mochic \& Ong, 2011); therefore this variable is taken into consideration to decode anti-branding in Turkey. Since religious values effect people's lifestyles and preferences, it was proposed that religiosity has positive significant impacts upon anti-branding. Contrary to expectations, religiosity has no significant effect on consumers supporting anti-branding. According to the results religiosity has a negative coefficient on female consumers supporting anti-branding. These negative coefficients present a new research idea for academicians to reveal the reasons related to this controversy.

\subsection{Conclusion}

As a conclusion, growing number of consumers reacting against consumer culture has raised researchers' attention towards negative concepts in order to define possible factors hindering companies from having a sustainable competitive power. In this context, revealing the motives behind consumers supporting anti branding and being able to satisfy these consumers expectations and needs could provide beneficiary results for both the 
consumers favoring anti branding and companies. This study has found out that ethnocentrism, environmental and health consciousness have significant roles in figuring out consumer activism against certain brands on the internet in this country context. Companies which give importance to these concepts in their marketing plans, policies and operations could be more appreciated by these consumers and thus they could address to a greater number of consumers. Thus, they could ensure higher level of consumer satisfaction, which might have positive influence on consumer commitment and loyalty besides decreasing the numbers and strength of Consumer Generated Anti-Branding on the Internet.

\subsection{Limitation}

There are several limitations belonging to this study and they might have negative impacts upon generalizing the results. First, data were collected through questionnaires instead of other qualitative methods. In addition, this study aims at revealing possible motives behind anti branding and puts forth an informative enthusiasm for new studies in this area. It could prove the proposed impacts of the determined antecedents upon anti branding except for religiosity and highlight the importance of ethnocentrism, environmental and health consciousness on Turkish consumers supporting anti-branding. Moreover, examining the variances explained in the dependent variables indicates that there are some other drivers leading anti-branding tendencies, which could be studied by future studies. Although, religiosity could not play a significant role in explaining the anti branding, this result is related to this country context; thus, studies that will be carried on in different countries might find out different results. Future studies might also emphasize some possible mediators changing the insignificant impact of religiosity upon the anti branding.

\subsection{Recommendations}

There are various strategies that could be suggested to companies according to the results of this study. While determining their operations in this country context, they should give importance to environmental and health related concerns in order to satisfy consumer's expectations besides their ethnocentric attitudes (Roberts \& Bacon, 1997; Chen \& Chai, 2010; Hong, 2009). Since consumers resist their products or brands not only silently and individually but also collectively through internet (Küçük, 2007), the policies of brands ignoring possible disastrous environmental outcomes might negatively affect their profits in the long run due to active websites favoring resistance against these brands. Thus, rather than operational level, they should integrate their concern for society's health and sustainable resources and environment into their main policies and company culture and convey their environmental consciousness through several media means such as their websites or internet advertisements. Such an internalization of the values related to environment and health could provide positive outcomes both for the companies themselves and the society. Furthermore, in order to prevent possible negative reactions of consumers supporting anti-branding, global companies should also consider their consumers' ethnocentric attitudes and define their brand management strategies in accordance with consumers' sensitivities for environment, health and ethnocentrism (Kaynak \& Kara, 2002).

\section{References}

Balabanis, G., \& Diamantopoulos, A. (2004). Domestic Country Bias, Country-of-Origin Effects, and Consumer Ethnocentrism: A Multidimensional Unfolding Approach. Journal of the Academy of Marketing Science, 32(1), 80-95. http://dx.doi.org/10.1177/0092070303257644

Ball, D. A., McCulloch, W. H., Frantz, P. L., Geringer, J. M., \& Minor, M. S. (2003). International Business: The Challenge of Global Competition. New York, NY: McGraw Hill.

Banerjee, B., \& McKeage, K. (1994). How green is my value: exploring the relationship between environmentalism and materialism. In Allen, C. T., \& John, D. R. (Eds.), Advances in Consumer Research, $21,147-52$.

Barrett, J. L. (2000). Exploring the natural foundations of religion. Trends in Cognitive Sciences, 4(1), $29-34$. http://dx.doi.org/10.1016/S1364-6613(99)01419-9

Bonne, K., \& Verbeke, W. (2006). Muslim consumer's attitude towards meat consumption in Belgium: insights from a means-end chain approach. Anthropology of Food, 5, 1-24.

Braunsberger, K., \& Buckler, R. B. (2011). What motivates consumers to participate in boycotts: Lessons from the ongoing Canadian seafood boycott. Journal of Business Research, 64, 96-102. http://dx.doi.org/10.1016/j.jbusres.2009.12.008

Campbell, C. (1990). Character and Consumption: A Historical Action Theory Approach to the Understanding of Consumer Behaviour. Culture \& History, 7, 37-48. 
Chen, T. B., \& Chai, L. T. (2010). Attitude towards the Environment and GreenProducts: Consumers' Perspective. Management Science and Engineering, 4(2), 27-39.

Cherrier, H. (2009). Anti-Consumption Discourses and Consumer Resistant-Identities. Journal of Business Research, 62(2), 181-190. http://dx.doi.org/10.1016/j.jbusres.2008.01.025

Choi, Y. (2009). Religion, religiosity, and South Korean consumer switching behaviors. Journal of Consumer Behaviour, 9(3), 157-171. http://dx.doi.org/10.1002/cb.292

Currie, J., DellaVigna, S., Moretti, E., \& Pathania, V. (2009). The effect of fast food restaurants on obesity. NBER Working Paper, 14721.

Diermeier, D., \& Mieghem, J. A. V. (2008). Voting with your pocketbook-a stochastic model of consumer boycotts. Mathematical and Computer Modelling, 48, 1497-1509. http://dx.doi.org/10.1016/j.mcm.2008.05.043

Divine, R. L., \& Lepisto, L. (2005). Analysis of the healthy lifestyle consumer. Journal of Consumer Marketing, 22(5), 275-283. http://dx.doi.org/10.1108/07363760510611707

Dutta-Bergman, M. J. (2004). Primary sources of health information: Comparisons in the domain of health attitudes, health cognitions, and health behaviors. Health Communication, 16(3), 273-288. http://dx.doi.org/10.1207/S15327027HC1603_1

Dutta-Bergman, M. J. (2006). A formative approach to strategic message targeting through soap operas: Using selective processing theories. Health Communication, 19(1), 11-18. http://dx.doi.org/10.1207/s15327027hc1901_2

Dutta-Bergman, M. J. (2007). Health information processing from television: The role of health orientation. Health Communication, 2l(1), 1-9. http://dx.doi.org/10.1080/10410230701283256

Essoo, N., \& Dibb, S. (2004). Religious influences on shopping behavior: An exploratory study. Journal of Marketing Management, 20, 683-712. http://dx.doi.org/10.1362/0267257041838728

Eye, A. V., \& Schuster, C. (1998). Regression Analysis for Social Sciences. California, USA: Academic Press.

Fagerli, R. A., \& Wandel, M. (1999). Gender differences in opinions and practices with regard to a "healthy diet". Appetite, 32, 171-190. http://dx.doi.org/10.1006/appe.1998.0188

Farah, M. F., \& Newman, A. J. (2010). Exploring consumer boycott intelligence using a socio-cognitive approach. Journal of Business Research, 63, 347-355. http://dx.doi.org/10.1016/j.jbusres.2009.03.019

Francis, L. J., \& Kaldor, P. (2002). The relationship between psychological well-being and Christian faith and practice in an Australian population sample. Journal for the Scientific Study of Religion, 41(1), 179-184. http://dx.doi.org/10.1111/1468-5906.00109

Grigsby, M. (2004). Buying Time and Getting by: The Voluntary Simplicity Movement. NY: State University of New York Press.

Hair, J. F. Jr., Anderson, R. E., Tatham, R. L., \& Black W. C. (1998). Multivariate data analysis (5th ed.). New Jersey: Prentice Hall.

Hoffmann, S., \& Müller, S. (2009). Consumer boycotts due to factory relocation. Journal of Business Research, 62(2), 239-47. http://dx.doi.org/10.1016/j.jbusres.2008.01.031

Hollenbeck, C. R., \& Zinkhan, G. M. (2006). Consumer Activism on the Internet: The Role of Anti-brand Communities. Advances in Consumer Research, 33, 479-485.

Holt, D. B. (2002). Why Do Brands Cause Trouble? A Dialectical Theory of Consumer Culture and Branding. Journal of Consumer Research, 29(1), 70-90. http://dx.doi.org/10.1086/339922

Hong, H. (2009). Scale Development for Measuring Health Consciousness: Re-conceptualization. 12th Annual International Public Relations Research Conference, Holiday Inn University of Miami Coral Gables, Florida.

Huneke, M. E. (2005). The Face of the Un-Consumer: An Empirical Examination of the Practice of Voluntary Simplicity in the United States. Psychology and Marketing, 22(7). http://dx.doi.org/10.1002/mar.20072

Iyer, R., \& James, A. M. (2008). A Purpose and object of anti- consumption. Journal of Business Research, 62(2), 160-168. http://dx.doi.org/10.1016/j.jbusres.2008.01.023

James, V. K. (2010). A socio-cultural approach to exploring consumer boycott intelligence: A commentary essay. 
Journal of Business Research, 63, 363-365. http://dx.doi.org/10.1016/j.jbusres.2009.04.015

Jayanti, R. K., \& Burns, A. C. (1998). The Antecedents of Preventive Health Care Behavior: An Empirical Study. Journal of the Academy of Marketing Science, 26(1), 6-15. http://dx.doi.org/10.1177/0092070398261002

Kaynak, E., \& Kara, A. (2002). Consumer perceptions of foreign products: An analysis of product-country images and ethnocentrism. European Journal of Marketing, 36(7/8), 928-949. http://dx.doi.org/10.1108/03090560210430881

Klein, J. G., \& Ettenson, R. (1999). Consumer Animosity and Consumer Ethnocentrism: An analysis of unique antecedents. Journal of International Consumer Marketing, 11, 5-24. http://dx.doi.org/10.1300/J046v11n04_02

Klein, J. G., John, A., \& Smith, C. N. (2001). Exploring Motivations for Participation in a Consumer Boycott. Centre for Marketing Working Paper, 01-701.

Kozinets, R. V., \& Handelman, J. M. (2004). Adversaries of Consumption: Consumer Movements, Activism and Ideology. Journal of Consumer Research, 31, 691-704. http://dx.doi.org/10.1086/425104

Krishnamurthy, S., \& Kucuk, S. U. (2009). Anti-branding on the internet. Journal of Business Research, 62, 1119-1126. http://dx.doi.org/10.1016/j.jbusres.2008.09.003

Kucuk, S. U. (2007). Negative Double Jeopardy: The role of anti-brand sites on the internet. Journal of Brand Management, 15(3), 209-222. http://dx.doi.org/10.1057/palgrave.bm.2550100

Lambert, J., \& Harrell, A. (2010). Imported Product Acceptance When National Origin Is Not An Issue: The Influence Of Personal Choice In A Low CETSCALE Environment. Journal of International Business Research, 9(1), 57-70.

Lee, M. S. W., Motion, J., \& Conroy, D. (2009). Anti-consumption and brand avoidance. Journal of Business Research, 62, 169-180. http://dx.doi.org/10.1016/j.jbusres.2008.01.024

Loewenthal, K. M., Macload, A. K., \& Cinnirella, M. (2002). Are women more religious than men? Gender differences in religious activity among different religious groups in the UK. Personality and Individual Differences, 32, 133-139. http://dx.doi.org/10.1016/S0191-8869(01)00011-3

Michaelidou, N., \& Hassan, L. (2008). The Push and Pull towards Organic: Clarifying the Roles of Health Consciousness, Food Safety Concern and Ethical Identity. International Journal of Consumer Studies, 32, 163-170. http://dx.doi.org/10.1111/j.1470-6431.2007.00619.x

Miller, A. S., \& Hoffmann, J. P. (1995). Risk and Religion: An Explanation of Gender Differences in Religiosity. Journal for the Scientific Study of Religion, 34(1). http://dx.doi.org/10.2307/1386523

Mokhlis, S. (2009). Relevancy and Measurement of Religiosity in Consumer Behavior Research. International Business Research, 2(3).

Moschis, G. P., \& Ong, F. S. (2011). Religiosity and consumer behavior of older adults: A study of subcultural influences in Malaysia. Journal of Consumer Affairs, 10(1), 8-17.

Mostafa, M. M. (2007). Gender differences in Egyptian consumers' green purchase behaviour: the effects of environmental knowledge, concern and attitude. International Journal of Consumer Studies, 31(3), 220-229. http://dx.doi.org/10.1111/j.1470-6431.2006.00523.x

Nguyen, T. T. M., Barrett, N. J., \& Nguyen, T. D. (2008). Consumer ethnocentrism, cultural sensitivity, and intention to purchase local products-evidence from Vietnam. Journal of Consumer Behaviour, 7(1), 88-100. http://dx.doi.org/10.1002/cb.238

Penaloza, L., \& Price, L. L. (2003). Consumer resistance: a conceptual overview. Adv Consum Res, 20(1), $123-128$.

Rahman, H., Morshed, M., \& Hossan, M. T. (2011). Identifying and Measuring Consumer Ethnocentric Tendencies in Bangladesh. World Review of Business Research, 1(1).

Ramsaran-Fowdar, R. R. (2010). Are Males and Elderly People more Consumer Ethnocentric ? World Journal of Management, 2(1), 117-129.

Reizenstein, R. C., Hills, G. E., \& Philpot, J. W. (1974). Willingness to pay for control of air pollution: a demographic analysis. In Curhan, R. C. (Ed.), 1974 Combined Proceedings (pp. 323-328). Chicago, IL: American Marketing Association. 
Rey, T. (2004). Marketing the goods of salvation: Bourdieu on religion. Religion, 34, 331-343. http://dx.doi.org/10.1016/j.religion.2004.09.008

Roberts, J. A., \& Bacon, D. R. (1997). Exploring the subtle relationships between environmental concern and ecologically conscious consumer behavior. Journal of Business Research, 40, 79-89. http://dx.doi.org/10.1016/S0148-2963(96)00280-9

Røpke, I. (1999). The Dynamics of Willingness to Consume. Ecological Economics, 28, 399-420. http://dx.doi.org/10.1016/S0921-8009(98)00107-4

Schlegelmilch, B. B., Greg, M. B., \& Adamantiosi, D. (1996). The link between green purchasing decisions and measures of environmental consciousness. European Journal of Marketing, 30(5), 35-55. http://dx.doi.org/10.1108/03090569610118740

Schwartz, S. H., \& Huismansi, S. (1995). Value Priorities and Religiosity in Four Western Religions. Social Psychology Quarterly, 58, 88-107. http://dx.doi.org/10.2307/2787148

Shankarmahesh, M. N. (2006). Consumer ethnocentrism: an integrative review of its antecedents and consequences. International Marketing Review, 23(2), 146. http://dx.doi.org/10.1108/02651330610660065

Sharma, S., Shimp, T. A., \& Shin, J. (1995). Consumer ethnocentrism: A test of antecedents and moderators. Journal of the Academy of Marketing Science, 23(1), 26-37. http://dx.doi.org/10.1007/BF02894609

Shimp, T. A., \& Sharma, S. (1987). Consumer Ethnocentrism: Construction and Validation of the CETSCALE. Journal of Marketing Research, 24, 280-289. http://dx.doi.org/10.2307/3151638

Steenkamp, J. B., Batra, R. E. M., \& Alden, D. (2003). How Perceived Brand Globalness creates brand value. Journal of International Business Studies, 34(1), 53-65. http://dx.doi.org/10.1057/palgrave.jibs.8400002

Stolz, J. (2009). Explaining religiosity: towards a unified theoretical model. The British Journal of Sociology, 60, 345-376. http://dx.doi.org/10.1111/j.1468-4446.2009.01234.x

Stroope, S. (2011). Education and religion: Individual, congregational, and cross-level interaction effects on biblical literalism. Social Science Research, 40(6), 1478-1493. http://dx.doi.org/10.1016/j.ssresearch.2011.05.001

Sujan, H., Weitz, B. A., \& Kumar, N. (1994). Learning Orientation, Working Smart, and Effective Selling. Journal of Marketing, 94(3), 39-52. http://dx.doi.org/10.2307/1252309

Sumner, W. G. (1906). Folkways. Boston: Ginn.

Vermeir, I., \& Verbeke, W. (2006). Sustainable Food Consumption: Exploring the Consumer Attitude-Behavioral Intention Gap. Journal of Agricultural and Environmental Ethics, 19(2). http://dx.doi.org/10.1007/s10806-005-5485-3

Wang, F., \& Reisner, A. (2011). Factors influencing private and public environmental protection behaviors: Results from a survey of residents in Shaanxi, China. Journal of Environmental Management, 92(3), 429-436. http://dx.doi.org/10.1016/j.jenvman.2010.08.002

Watson, J. J., \& Wright, K. (2000). Consumer ethnocentrism and attitudes towards domestic and foreign products. European Journal of Marketing, 34(9/10), 1149-1166. http://dx.doi.org/10.1108/03090560010342520

Winit, W., Gregory, G., \& Mascio, R. D. (2008). For Love of Country: Consolidating Ethnocentrism, Patriotism, and Consumer Openness Measures in Thailand. The Australian \& New Zealand Marketing Academy Conference.

Worthington, E. L., Worthington, Jr., Wade, N. G., Hight, T. L., Ripley, J. S., McCullough, M. E., Berry, J. W., Schmitt, M. M., Berry, J. T., Bursley, K. H., \& O'Connor, L. (2003). The Religious Commitment Inventory-10: Development, refinement, and validation of a brief scale for research and counseling. Journal of Counseling Psychology, 50, 84-96. http://dx.doi.org/10.1037/0022-0167.50.1.84

\section{Copyrights}

Copyright for this article is retained by the author(s), with first publication rights granted to the journal.

This is an open-access article distributed under the terms and conditions of the Creative Commons Attribution license (http://creativecommons.org/licenses/by/3.0/). 